\title{
mRNA COVID-19 vaccine: A future hope for cancer treatment
}

\author{
Yadav AK ${ }^{1 *}$, Gnawali $S^{2}$, Mandal $S^{3}$, Shrestha $G^{4}$, Yuan $G^{5}$
}

*Corresponding author:

Mr. Ajay Kumar Yadav, PhD Scholar, Nuclear Medicine, The Second Affiliated Hospital of Chongqing Medical University, PR China

Email: ajay_bpkmch@hotmail.com ORCID

\section{Information about the article:}

Received: Nov 28, 2021

Accepted: Dec 25, 2021

Published online: Dec 31, 2021

\section{Cite this article:}

Yadav AK, Gnawali S, Mandal S, Shrestha GB, Yuan G. mRNA COVID-19 vaccine: A future hope for cancer treatment. Journal of Biomedical Sciences. 2021;8(2):47-49

\section{Publisher}

Nepal Health Research Society, Bahundhara -6 , Gokarnesowor Municipality, Kathmandu, Nepal eISSN 2382-5545, ISSN 2676-1343 (Print)

(C) The Author(s). 2021

Content licensing: CC BY 4.0

\section{ABSTRACT}

\section{Background}

mRNA vaccines have a strong potential for a possible cancer therapy platform. They express tumor antigens in antigen-presenting cells (APCs) after immunization, facilitating innate/adaptive immune stimulation. Because of its high effectiveness, safe administration, rapid development potential, and cost-efficient manufacturing, the mRNA cancer vaccine surpasses other traditional vaccination platforms.

\section{Conclusion}

Careful evaluation of promising mRNA vaccines to supervise as carriers of lipids for cancer patients needs to be done. In addition, a possible revaluation for optimal protection is required. However, the extent to which solid tumours might take a significant part of the vaccine doses is still unknown.

\section{Keywords}

Carcinoma, COVID-19, DNA, mRNA, nanoparticles, tumour 


\section{Background}

COVID-19 epidemic has endorsed the international development of vaccines at speed up, and more than one hundred eighty missions are at present reached the clinical assessment stages [1]. The recognition of direct SARSCoV-2 Spike protein (S) of the enzyme angiotensinconverting enzyme-2 has led to two types of vaccines that are equal to this protein [2]. After specific genetic management, the first one is based on an inactivated virus that conveyed the Spike protein $(\mathrm{S})$. The second one is based on the insertion of nucleotides (i.e., mRNA or DNA) that guide the synthesis of protein (S) from the human being.

Until now, the structures of mRNA were the first to arrive at the third stage of the tests with a promising return. For physical-chemical and biological strength reasons, the mRNA Spike protein (S) must be encapsulated in liposomes and carried as lipid nanoparticles. Among the populations to benefit from vaccination of COVID-19 will be the mainly fragile citizens, such as carcinoma patients, for whom COVID-19 can be especially unfavourable [3].

There is a significantly older story of anti-cancer representatives in liposomes such as vectors drugs in carcinoma patients, together with the supply of nucleotides, such as tiny intrusive RNA [4]. Liposome's interferences are projected to gather in passive focus tumour cells, a better-known incident as the best permeation and retention effect (EPR). Two hundred nanometers characterise most tumour vasculatures due to fenestrations of non-junctive endothelial tissues, a small sheet of smooth musculature, less control of homeostatic bloodstream, and decreased angiotensin appearance second receptors and lofty levels of vascular permeability aspects [5]. All these features clarify how losses can be in the tumour environment, which makes nanoparticles effortlessly disappear the flow of blood cells and tumour flow, as long as its size is less than two hundred nanometers. Abridged lymphatic flow additional elucidates why nanoparticles will accrue in the tumour micro-environment behind leakage escape [6]. The experimental data in the tumour have already demonstrated how the EPR outcome depends on the liposomes' dimension, is to say, minor size of tumour accumulation. In general, the EPR effect leads to five to ten per cent of the injected dosage established in bigger nano-particle tumours, and up to twenty-five per cent for the little ones, should be in models. An affirmative association was also established among the gathering of liposomes in tumours and vascular concentration: the densest the blood vessels, the superior the spread of tumours [7]. In human beings, the EPR effect was longestablished. The highest concentrations of drug in tumours solid they observed in patients treated with cytotoxic agents liposomal cancer than those with administration [8].
Drug-free as far as the truth that a few of the majority highly developed COVID-19 vaccine applicants are stand on providing mRNA employing liposomes; this also elevates the query of likely hiring vaccines from tumour fabrics. In fact, as for most proteins that are distributed employing lipid carriers, two vaccinations in advance (i.e., the mRNA-1273 and BNT162b2 of Pfizer) are distributed is smaller than two hundred nano-meters nanoparticles [9]. As a result, it also leads to EPR outcomes, with most major tumours gathering in the environment, since for any other medicine specified as liposomes. At what point is this specific deliverance for tumour tissues might be a problem in patients with carcinoma \& so, leftovers to be assessed. As a result of protection, the extent of the vaccine dosage COVID-19 must be re-evaluated for an assumption that a likely intake of liposomes of tumour tissues deserves consideration. Vaccines COVID-19 are provided as lipids airlines are administered intramuscularly (IM). Pre-clinical statistics have revealed that the protein encapsulated in liposomes and IM administration guide general circulation in human beings [10].

One more conceivable result of the particular conveyance of the Spike protein as liposomal structure to malignant growth cells could be altered cancer invulnerability, with a potential expected effect on the advancement of the sickness and a potential change in the affectability of immunotherapy. However, these special effects are still unidentified; this requires meticulous research by decoding the significance of the liposome vaccine in tumour biology.

\section{Conclusion}

The cautious assessment of the immunisations mRNA Coronavirus managed as transporters of fat ought to be applied to patients with strong growths, including a potential revaluation of the examined for ideal assurance of this particular populace. Likewise, a cautious assessment of the mRNA immunisations managing as transporters of lipids for malignant growth patients includes a potential revaluation.

\section{Abbreviation}

Deoxyribonucleic acid (DNA), messenger Ribonucleic acid (mRNA), permeation and retention effect (EPR), intramuscularly (IM), spike protein (S)

\section{Acknowledgments}

We would like to thank the Department of Radio-diagnosis, Imaging and Nuclear Medicine and the Department of pathology for the swift and efficient support to make this work possible.

\section{Authors' contribution}

a. Study planning: AKY, YG 
b. Manuscript writing: AKY, SG

c. Manuscript revision: YG, AKY, GBS

d. Final approval: AKY, NG, SM, GBS, YG

e. Agreement to be accountable for all aspects of the work:

AKY, NG, SM, GBS, YG

\section{Funding}

There was no funding for this work.

\section{Availability of data and materials}

Not Applicable.

\section{Competing interests}

All authors declare that there are no conflicts of interests or competing interests regarding the material in this manuscript.

\section{Publisher's Note}

NHRS remains neutral with regard to jurisdictional claims in published maps and institutional affiliations.

The publisher shall not be legally responsible for any types of loss, actions, claims, proceedings, demand or costs or damages whatsoever or howsoever caused arising directly or indirectly in connection with or arising out of the use of this material.

\section{Author information}

${ }^{1}$ Ajay Kumar Yadav, Department of Nuclear Medicine, The Second Affiliated Hospital of Chongqing Medical University, PR China ORCID

${ }^{2}$ Suman Gnawali, Technologist BMIT, Department of Radiology \& Nuclear Medicine, BP Koirala Memorial Cancer Hospital, Bharatpur, Nepal ORCID

${ }^{3}$ Sandip Mandal, Technologist BMIT, Department of Radiology \& Nuclear Medicine, BP Koirala Memorial Cancer Hospital, Bharatpur, Nepal ORCID

${ }^{4}$ Gyan Bahadur Shrestha, Senior Consultant, Department of Radiology \& Nuclear Medicine, BP Koirala Memorial Cancer Hospital, Bharatpur, Nepal ORCID ${ }^{5}$ Yuan Gangbiao, MD, Ph.D. Professor, Department of Nuclear Medicine, The Second Affiliated Hospital of Chongqing Medical University, PR China ORCID

\section{References}

1. Krammer F. SARS-CoV-2 vaccines in development. Nature. 2020;586(7830):516-27. https://doi.org/10.1038/s41586-020-2798-3

2. Brest P, Refae S, Mograbi B, Hofman P, Milano G. Host Polymorphisms May Impact SARS-CoV-2 Infectivity. Trends in Genetics. 2020;36(11):81315. https://doi.org/10.1016/j.tig.2020.08.003
3. Gosain R, Abdou Y, Singh A, Rana N, Puzanov I, Ernstoff M. COVID-19 and Cancer: a Comprehensive Review. Current Oncology Reports. 2020;22(5):53 https://doi.org/10.1007/s11912-020-00934-7

4. Boca S, Gulei D, Zimta A, Onaciu A, Magdo L, Tigu A et al. Nanoscale delivery systems for microRNAs in cancer therapy. Cellular and Molecular Life Sciences. 2019;77(6):1059-86. https://doi.org/10.1007/s00018-019-03317-9

5. van Eerden R, Mathijssen R, Koolen S. Recent Clinical Developments of Nanomediated Drug Delivery Systems of Taxanes for the Treatment of Cancer. International Journal of Nanomedicine. 2020; Volume 15:8151-66. https://doi.org/10.2147/IJN.S272529

6. Maeda H, Bharate G, Daruwalla J. Polymeric drugs for efficient tumor-targeted drug delivery based on EPR-effect. European Journal of Pharmaceutics and Biopharmaceutics. 2009;71(3):409-19.

https://doi.org/10.1016/j.ejpb.2008.11.010

7. Fanciullino R, Mollard S, Correard F, Giacometti S, Serdjebi C, Iliadis A et al. Biodistribution, Tumor Uptake and Efficacy of 5-FU-Loaded Liposomes: Why Size Matters. Pharmaceutical Research. 2014;31(10):2677-84. https://doi.org/10.1007/s11095-014-1364-9

8. Atrafi F, van Eerden R, van Hylckama Vlieg M, Oomen-de Hoop E, de Bruijn P, Lolkema M et al. Intratumoral Comparison of Nanoparticle Entrapped Docetaxel (CPC634) with Conventional Docetaxel in Patients with Solid Tumors. Clinical Cancer Research. 2020;26(14):3537-45 https://doi.org/10.1158/1078-0432.CCR-20-0008

9. Pardi N, Tuyishime S, Muramatsu H, Kariko K, Mui B, Tam Y et al. Expression kinetics of nucleoside-modified mRNA delivered in lipid nanoparticles to mice by various routes. Journal of Controlled Release. 2015;217:345-51. https://doi.org/10.1016/j.jconrel.2015.08.007

10. Li H, Yang L, Cheng G, Wei H, Zeng Q. Encapsulation, pharmacokinetics and tissue distribution of interferon $\alpha-2 b$ liposomes after intramuscular injection to rats. Archives of Pharmacal Research. 2011;34(6):941-8. https://doi.org/10.1007/s12272-011-0611-4 